\title{
Correlates of substance use during adolescent pregnancy in São Paulo, Brazil
}

\section{Correlatos do uso de substâncias durante a gravidez na adolescência em São Paulo, Brasil}

\author{
Marco Antonio Bessa, ${ }^{1}$ Sandro Sendin Mitsuhiro, ${ }^{1}$ Elisa Chalem,,${ }^{1,2}$ Marina Carvalho de Moraes Barros, ${ }^{3}$ \\ Ruth Guinsburg, ${ }^{3}$ Ronaldo Laranjeira ${ }^{1}$ \\ 1 Alcohol and Drugs Research Unit (UNIAD), Psychiatry Department, Universidade Federal de São Paulo (Unifesp), São Paulo (SP), Brazil \\ 2 Mário de Moraes Altenfelder Silva Maternity Hospital, São Paulo (SP), Brazil \\ 3 Pediatrics Department, Universidade Federal de São Paulo (UNIFESP), São Paulo (SP), Brazil
}

\begin{abstract}
Objective: To investigate the association of cocaine and marijuana use during adolescent pregnancy in São Paulo-SP, Brazil, with psychiatric disorders, social status and sexual history. Method: One thousand pregnant adolescents were assessed by using the Composite International Diagnostic Interview, and sociodemographic and socio-economic questionnaire at the obstetric center of a public hospital in São Paulo. Hair samples were collected for analysis. Results: The following data were associated with cocaine and/or marijuana use during the third trimester of the pregnancy: being younger than 14 years of age, having a history of more than 3 sexual partners, and having psychiatric disorders, specifically, bipolar disorder, post-traumatic stress disorder, and somatoform disorder. Conclusion: In early adolescence pregnancy, having 3 or more sexual partners in life for this population is significantly associated with the use of cocaine or marijuana during gestation. This association suggests that specific intervention programs should target these young women.
\end{abstract}

Descriptors: Pregnancy in adolescence; Comorbidity; Substance-related disorders; Cocaine; Cannabis

\section{Resumo}

Objetivo: Investigar, numa população de gestantes adolescentes de uma maternidade pública de São Paulo-SP, Brasil, a associação entre o consumo de cocaina e maconha durante a gravidez com distúrbios psiquiátricos, status social e história sexual. Método: Mil adolescentes grávidas foram avaliadas por meio do Composite International Diagnostic Interview e de um questionário sociodemográfico e socioeconômico no centro obstétrico de um hospital público de São Paulo. Destas, foi colhida amostra para análise de fios de cabelo. Resultados: Os seguintes dados foram associados com o uso de cocaina elou maconha durante o terceiro trimestre de gravidez: ter menos de 14 anos, ter história de mais do que três parceiros sexuais e ter transtornos psiquiátricos, em especial, transtorno afetivo bipolar, transtorno do estresse pós-traumático e transtorno somatoforme. Conclusão: Na população de adolescentes grávidas avaliada, ter menos de 14 anos e ter três ou mais parceiros sexuais na vida está significativamente associado ao uso de maconha ou cocaina durante a gestação. Esta associação sugere que programas de intervenção especificos devem ser dirigidos a essas jovens.

Descritores: Gravidez na adolescência; Comorbidade; Transtornos relacionados ao uso de substâncias; Cocaina; Maconha

\section{Introduction}

The use of illicit drugs by pregnant teenagers is of considerable interest due to the fact that there is consistent evidence in the scientific literature that this behavior may cause multiple complications for both the baby and the mother. This is particularly true in regards to the use of cocaine. ${ }^{1}$ Also, sensitive neurobehavioral instruments have established the negative effects of intra-uterine exposure to marijuana. ${ }^{2,3}$ Moreover, there are negative economic and social impacts which are well documented for both drugs. ${ }^{4}$ There are few studies made in Brazil on this subject $^{5-7}$ and only one used hair test to detect drug use. ${ }^{8}$
Determining the correlates of the use of drugs during pregnancy in teenagers may have implications for the formulation of preventive programs. Thus, the aim of this study was to investigate the association of cocaine and marijuana use during adolescent pregnancy in São Paulo, Brazil, with psychiatric disorders, social status and sexual history of the mothers.

\section{Method}

A convenience sample of 1000 pregnant teenage women who were inpatients at the obstetric center of Mario de Moraes Altenfelder Silva Maternity Hospital was invited to participate. 
This facility is a public hospital located in the northern region of the city of São Paulo, the largest city in Brazil, which caters mostly to a local low-income population. The data collection started on July 24, 2001, and finished on November 27, 2002. All patients provided informed consent and no patient refused to participate. The study was approved by the ethics committee of the hospital and that of the Universidade Federal de São Paulo.

The presence of a psychiatric diagnosis was assessed by the validated Brazilian version of the Composite International Diagnostic Interview, 2.1 version (CIDI). ${ }^{9}$ This instrument is a fully structured diagnostic interview, which generates diagnoses according to the International Classification of Diseases $-10^{\text {th }}$ version (ICD-10) and the Diagnostic and Statistical Manual of Mental Disorders $-4^{\text {th }}$ version (DSM-IV). The version for detecting diagnoses in the previous 12 months, which is a period that includes the months of pregnancy, was used.

The prevalence of the use of cocaine and marijuana during the last trimester of pregnancy was assessed by hair analysis through the combination of the Enzyme-Linked Immunosorbent Assay (ELISA) and the Gas Chromatography Mass Spectrometry (GCMS), for tracing and confirmation, respectively. ${ }^{10}$ Hair samples permit the detection of drugs use over a long time period. The period measured is limited only by the length of the hair, since the drugs metabolites are permanently deposited in the protein matrix of hair. ${ }^{11}$ Head hair grows at an average rate of $1.3 \mathrm{~cm} /$ month. ${ }^{12}$ Research staff cut a hair sample as close to the scalp as possible near the crown of the head. The length of hair was cut to a maximum of $3.9 \mathrm{~cm}$ representing about three months of grow.

The socio-demographic, socio-economic, psychosocial and sexual behavior data were assessed by using a questionnaire developed and adapted from the Perinatal Needs Assessment (PNA), ${ }^{13}$ which included information about the patient's age, address, place of birth, marital status, schooling, school dropout status, employment, professional training, family planning, use of birth control methods, sexual habits, age of initial sexual activity, and number of children. A Brazilian socioeconomic classification was used ${ }^{14}$ which is based on the educational level of the head of the household, the number of domestic electric appliances in the household, and family income. It classifies individuals in 5 different categories (A to E), and these were collapsed into three larger ones: high (A and B), middle(C) and low (D and $\mathrm{E})$.

Statistical analysis was performed considering the third-trimester cocaine and/or marijuana use (yes or no) as the dependent variable. For the bivariate analysis of the data we used the Student's $t$ test for independent groups (quantitative variables) and the Chisquare test (categorical variables). For the multivariate analysis, we constructed a logistic regression model (enter method) with the age of the teenage women and all the independent variables with $\mathrm{p}<0.25$ on the bivariate analysis. Odds ratio was estimated constructing 95\% confidence intervals and Wald test was used to decide about the significance of each variable. Significance was defined as $\mathrm{p}<0.05$. Data were analyzed using SPSS for windows version 14.0.

\section{Results}

The use of hair analysis allowed us to detect the use of cocaine and/or marijuana in the third trimester of pregnancy in $6 \%$ of the patients (marijuana: $4 \%$; cocaine: $1.7 \%$; both: $0.3 \%$ ). The prevalence of cocaine and/or marijuana use and of psychiatric disorders, as well as description of the sample and detailed characteristics of the social status, sexual history and current gestation, and obstetric evolution of this population were described in a previous paper. ${ }^{8}$ The most important characteristics found were: the mean age of these teenage mothers was 17.12 (SD 1.5), 93.4\% of this sample were from low-income (C, D and E classes), only $7.2 \%$ were married, $67.3 \%$ dropped out of school ${ }^{8}$ and $91.2 \%$ attended prenatal care. ${ }^{7}$

Table 1 shows the association of cocaine and/or marijuana use during the third trimester of pregnancy of these adolescent women with psychiatric disorders and with demographic factors. Values of $\mathrm{p}$ in the univariate analysis and multivariate analysis, as well as odds ratio estimates (95\% confidence interval) are presented. The application of the multivariate model established the association of cocaine and/or marijuana use during third trimester of pregnancy with some psychiatric disorders (bipolar disorder, post-traumatic stress disorder and somatoform disorder) and having a history of more than 3 sexual partners or being younger than 14 years of age.

\section{Discussion}

Age is a factor that is significantly associated with the consumption of at least one type of drug. The fact that the OR was significantly lower than 1 ( 0.15 to 0.98$)$ indicates that being older than 14 years mitigates against the consumption of cocaine or marijuana. From another perspective, being younger than 14 years is associated with an increase in the probability of using one of these drugs. Unfortunately, the design of our study does not allow us to pinpoint the reasons for this observation. However, we can infer that risk-taking behavior may be a pattern for this group. Regardless of this, these findings suggest that specific intervention programs should target these young women.

Having 3 or more sexual partners in life for this population is significantly associated with the use of cocaine or marijuana during pregnancy. After the societal behavioral changes that have occurred in the last several decades, especially in terms of sexual behavior outside of marriage, having multiple partners is very common, even among adolescents. The results of this study show that these girls are at particular risk for using drugs during pregnancy.

We found no associations with other sociodemographic or sexual behavior factors among the ones we investigated in this sample. However, the associations with some psychiatric disorders are very robust. Somatoform, Bipolar, and Post-traumatic Stress Disorders are significantly associated with the use of cocaine or marijuana. All the developmental tasks involved in adolescence exposes this population to an increased risk of psychological dysfunction. Moreover, there is consistent evidence in the literature about the correlation between poverty, low education, lack of social and family support, teenage pregnancy, use of 
Table 1 - The association of cocaine and/or marijuana use during the third trimester of pregnancy of adolescents with psychiatric disorders and social status and sexual history

\begin{tabular}{|c|c|c|c|c|c|c|c|c|}
\hline Variables & $\begin{array}{c}\text { Risk } \\
\text { classificatio }\end{array}$ & $\begin{array}{l}\text { Positive cocaine } \\
\text { and/or marijuana in } \\
\text { hair testing } \\
(n=834)\end{array}$ & $\begin{array}{l}\text { Negative } \\
\text { cocaine and/or } \\
\text { marijuana in } \\
\text { hair testing } \\
(n=166)\end{array}$ & $\begin{array}{c}\text { p value }^{*} \\
\text { (bivariate) }\end{array}$ & $\begin{array}{c}\text { p value }{ }^{* *} \\
\text { (multivariate) }\end{array}$ & O.R. & $\begin{array}{l}\text { Inferior } \\
\text { limit of } \\
95 \% \mathrm{CI}\end{array}$ & $\begin{array}{l}\text { Superior } \\
\text { limit of } \\
95 \% \mathrm{Cl}\end{array}$ \\
\hline Age & $\leq 14 \mathrm{y}$. & $42(5.0 \%)$ & $9(5.4 \%)$ & 0.837 & 0.044 & 2.62 & 1.02 & 6.68 \\
\hline $\mathrm{N}^{\circ}$ of alive children & $\geq 2$ & $120(14.4 \%)$ & $32(19.4 \%)$ & 0.105 & 0.882 & 0.98 & 0.70 & 1.36 \\
\hline Working status & $\begin{array}{c}\text { Mean } \\
\text { number of } \\
\text { months at } \\
\text { work } \pm S D\end{array}$ & $1.6 \pm 3.4$ & $2.2 \pm 3.7$ & 0.137 & 0.379 & 1.02 & 0.97 & 1.08 \\
\hline Schooling years & $\begin{array}{l}\text { Mean } \\
\text { number of } \\
\text { years in } \\
\text { school } \pm \\
\text { SD }\end{array}$ & $7.6 \pm 2.3$ & $7.5 \pm 2.3$ & 0.144 & 0.091 & 1.15 & 0.98 & 1.34 \\
\hline Currently in school & No & $549(65.9 \%)$ & $123(74,1 \%)$ & 0.040 & 0.361 & 1.23 & 0.79 & 1.90 \\
\hline $\begin{array}{l}\text { Difference between } \\
\text { age and schooling }\end{array}$ & $\begin{array}{c}\text { Mean } \\
\text { number of } \\
\text { years } \pm S D\end{array}$ & $9.3 \pm 2.4$ & $9.8 \pm 2.3$ & 0.030 & 0.185 & 1.11 & 0.95 & 1.30 \\
\hline Pre-natal care & No & $67(8.1 \%)$ & $21(12.7 \%)$ & 0.053 & 0.154 & 1.54 & 0.85 & 2.81 \\
\hline $\begin{array}{l}\text { Depression } \\
\text { disorder }\end{array}$ & Yes & $97(11.6 \%)$ & $32(19.3 \%)$ & 0.007 & 0.117 & 1.49 & 0.90 & 2.45 \\
\hline Anxiety disorders & Yes & $41(4.9 \%)$ & $15(9.0 \%)$ & 0.035 & 0.272 & 1.50 & 0.73 & 3.08 \\
\hline $\begin{array}{l}\text { Post-traumatic } \\
\text { stress disorder }\end{array}$ & Yes & $71(8.7 \%)$ & $29(17.8 \%)$ & $<0.001$ & 0.018 & 1.88 & 1.11 & 3.17 \\
\hline Bipolar disorder & Yes & $6(0.7 \%)$ & $6(3.6 \%)$ & 0.007 & 0.015 & 4.67 & 1.35 & 16.16 \\
\hline Psychotic disorders & Yes & $25(3.0 \%)$ & $10(6.0 \%)$ & 0.053 & 0.350 & 1.56 & 0.61 & 4.00 \\
\hline $\begin{array}{l}\text { Dissociative } \\
\text { disorder }\end{array}$ & Yes & $1(0.1 \%)$ & $2(1.2 \%)$ & 0.073 & 0.077 & 10.21 & 0.77 & 134.97 \\
\hline $\begin{array}{l}\text { Somatoform } \\
\text { disorder }\end{array}$ & Yes & $7(0.8 \%)$ & $12(7.2 \%)$ & $<0.001$ & $<0.001$ & 10.22 & 3.83 & 27.26 \\
\hline Eating disorders & Yes & $1(0.1 \%)$ & $2(1.2 \%)$ & 0.073 & 0.427 & 2.90 & 0.21 & 40.39 \\
\hline $\begin{array}{l}\text { Sexual partners in } \\
\text { life }\end{array}$ & $\geq 3$ & $168(20.3 \%)$ & $61(37.0 \%)$ & $<0.001$ & $<0.001$ & 2.07 & 1.37 & 3.13 \\
\hline
\end{tabular}

Significant if $p$-value $<0.05$

Results are expressed by frequency (percent) or mean \pm standard deviation

* $t$-test or Chi-square test, $p<0.05$

** Logistic Regression Model and Wald test, $p<0.05$

Third-trimester cocaine and/or marijuana use is the dependent variable for bivariate and multivariate analysis

drugs, and psychopathology. ${ }^{15}$ These factors contribute to an ongoing low socio-economic status, creating a situation of lack of opportunities in life. For these young women, using drugs and getting pregnant may be an attempt to escape the harsh realities of life, and psychiatric disorders may be another kind of problem that aggravates this reality.

\section{Conclusion}

The associations of pregnancy in early adolescence and having multiple sexual partners with the use of cocaine and marijuana during pregnancy suggest that specific intervention programs should target these young women. 


\section{Disclosures}

\begin{tabular}{|c|c|c|c|c|c|c|c|}
\hline $\begin{array}{l}\text { Writting group } \\
\text { member }\end{array}$ & Employment & $\begin{array}{l}\text { Research } \\
\text { grant }^{1}\end{array}$ & $\begin{array}{l}\text { Other research grant or } \\
\text { medical continuous } \\
\text { education }^{2}\end{array}$ & $\begin{array}{l}\text { Speaker's } \\
\text { honoraria }\end{array}$ & $\begin{array}{c}\text { Ownership } \\
\text { interest }\end{array}$ & $\begin{array}{l}\text { Consultant/ } \\
\text { Advisory } \\
\text { board }\end{array}$ & Other $^{3}$ \\
\hline $\begin{array}{l}\text { Marco Antonio } \\
\text { Bessa }\end{array}$ & UNIAD & FAPESP & - & - & - & - & - \\
\hline $\begin{array}{l}\text { Sandro Sendin } \\
\text { Mitsuhiro }\end{array}$ & UNIAD & FAPESP & - & - & - & - & - \\
\hline Elisa Chalem & UNIAD & - & - & - & - & - & - \\
\hline Ruth Guinsburg & UNIFESP & FAPESP & - & - & - & - & - \\
\hline $\begin{array}{l}\text { Ronaldo } \\
\text { Laranjeira }\end{array}$ & $\begin{array}{l}\text { UNIAD } \\
\text { UNIFESP }\end{array}$ & FAPESP & - & - & - & - & - \\
\hline $\begin{array}{l}\text { Modest } \\
\text { * Significant } \\
\text { ** Significant. Amou } \\
\text { Note: UNIAD = Alcol } \\
\text { Estado de São Paulo } \\
\text { Eormore information }\end{array}$ & $\begin{array}{l}\text { ven to the auth } \\
\text { dd Drugs Rese } \\
P q=\text { Conselho } \\
\text { Instructions fo }\end{array}$ & $\begin{array}{l}\text { nstitution or } \\
\text { Unit; UNIFL } \\
\text { onal de Des } \\
\text { ors. }\end{array}$ & $\begin{array}{l}\text { colleague for research in } \\
=\text { Universidade Federal de } \\
\text { Ivimento Científico e Tecn }\end{array}$ & $\begin{array}{l}\text { he the autho } \\
\text { ão Paulo; } F \\
\text { gico. }\end{array}$ & $\begin{array}{l}\text { s participatio } \\
\text { ESP }=\text { Funda }\end{array}$ & $\begin{array}{l}\text { not directly to } t \\
\text { o de Amapro }\end{array}$ & $\begin{array}{l}\text { author. } \\
\text { esquisa } d\end{array}$ \\
\hline
\end{tabular}

References

1. Wolfe EL, Davis T, Guydish J, Delucchi KL. Mortality risk associated with perinatal drug and alcohol use in California. J Perinatol. 2005;25(2):93100.

2. Barros MM, Guinsburg R, Peres CA, Mitsuhiro SS, Chalem E, Laranjeira R. Exposure to marijuana during pregnancy alters neurobehavior in the early neonatal period. J Pediatr. 2006;149(6):781-7.

3. Lester BM, Tronick EZ, LaGasse L, Seifer R, Bauer CR, Shankaran S, Bada HS, Wright LL, Smeriglio VL, Lu J, Finnegan LP, Maza PL. The maternal lifestyle study: effects of substance exposure during pregnancy on neurodevelopmental outcome in 1-month-old infants. Pediatrics. 2002;110(6):1182-92.

4. Anderson M, Elk R, Andres RL. Social, ethical and practical aspects of perinatal substance use. J Subst Abuse Treat. 1997;14(5):481-6.

5. Caputo VG, Bordin IA. Teenage pregnancy and frequent use of alcohol in the home enviroment. Rev Saude Publica. 2008;42(3):402-10.

6. Gama SN, Szwarcwald CL, Sabroza AR, Castelo Branco V, Leal Mdo C. Factors associated with precarious prenatal care in a sample of post-partum adolescent mothers in maternity hospitals in Rio de Janeiro, Brazil, 1999-2000. Cad Saude Publica. 2004;20(Supl.1):S101-11.

7. Chalem E, Mitsuhiro SS, Ferri CP, Barros MM, Guinsburg R, Laranjeira R. Teenage pregnancy: behavioral and socio demographic profile of an urban Brazilian population. Cad Saude Publica. 2007;23(1):177-86.

8. Mitsuhiro SS, Chalem E, Barros MM, Guinsburg R, Laranjeira R. Teenage pregnancy: use of drugs in the third trimester and prevalence of psychiatric disorders. Rev Bras Psiquiatr. 2006;28(2):122-5.

9. Quintana MI, Andreoli SB, Jorge MR, Gastal FL, Miranda CT. The reliability of the Brazilian version of the Composite International Diagnostic Interview (CIDI 2.1). Braz J Med Biol Res. 2004;37(11):1739-45.

10. Huestis MA, Cone, EJ. Alternative testing matrices. In: Karch SB, editor. Drug abuse handbook. Boca Raton, FL: CRC Press; 1998. p.799-857.

11. Kuhn L, Kline J, Ng SC, Levin B, Susser M. Cocaine use during pregnancy and intrauterine growth retardation: new insights on maternal hair tests. Am J Epidemiol. 2000;152(2):112-9.

12. Kline J, Ng SC, Schittini M, Levin B, Susser M. Cocaine use during pregnancy: sensitive detection by hair assay. Am J Public Health. 1997;87(3):352-8.

13. Zahnd E, Klein D, Needell B. Substance use and issues of violence among low income pregnant women: The California Perinatal needs assessment. $J$ Drug Issues. 1997;27(3):563-84.

14. Associação Nacional de Empresas de Pesquisa - ANEP. Critério de classificação econômica Brasil. São Paulo: ANEP; 1997. p10.

15. Rome ES, Rybicki LA, Durant RH. Pregnancy and other risk behaviors among adolescent girls in Ohio. J Adolesc Health. 1998;22(1):50-5. 